\title{
MIRRORING THE EU? FUNCTIONAL CAPACITY OF INTEGRATION IN ASIA
}

\author{
Vlad Vernygora ${ }^{1,2,3}$, Natalia Chaban ${ }^{2}$, and Chae-Deug $\mathrm{Yi}^{1}$ \\ ${ }^{1}$ Pusan National University, South Korea, ${ }^{2}$ University of Canterbury, \\ New Zealand, and ${ }^{3}$ Tallinn University of Technology
}

\begin{abstract}
This paper contributes to the debate on the multidimensional phenomenon of Asian regional integration. Considering one case study - a regional grouping known as 'ASEAN+3' - this paper offsets it against relevant achievements on the European continent. Admitting that direct application of the EU's model to the ASEAN+3 frameworks is fruitless, this study uses a different approach, treating the EU's legal composition as a leading tool to assess if the European 'know how' in regional integration could be applied to facilitate the inter-relations within the ASEAN +3 .

Three barriers to regional integration are explored: differing democratic practices, dominating intergovernmental interactions, and the globally (vs. regionally) orientated China. Yet, this paper argues that the aforementioned challenges have a potential not only to subvert, but, paradoxically, reinforce the Asian integration process, particularly within the ASEAN+3 grouping.
\end{abstract}

Keywords: Asian integration, ASEAN+3, functional capacity of integration, the EU's legal profile

DOI: $10.3176 /$ tr.2012.1.02

\section{Introduction}

The on-going wave of the European integration has never been caused by a pleasant breeze of prosperous life in a quiet neighborhood. On the contrary, it was the devastating 'tsunami' of World War II that brought up a novel and controversial idea of a more cohesive Europe. In 1950, a European visionary, the then French Foreign Minister Robert Schuman, proposed a plan that has changed modern European (and global) geo-political landscape. Inspired by Jean Monnet's pragmatic idealism and backed by Konrad Adenauer's idealistic pragmatism (Vernygora and Chaban 2008a:153), the 1950 Schuman Declaration heralded a 
new phase in and interpretation of the ever present European regionalism. It laid the legal foundation to a conceptually new framework of intergovernmental cooperation - the one that suggests a mutual compromise in sovereignty, an unheard development for European nation-states in the past. That particular vision later became a solid base for what is now known as the European Union (EU).

Counting 27 Member States in 2011, the EU is bound by its members' firm commitment to the principles of peace, rule of law, liberal democracy, human rights protection and free market. This commitment is vital in creating a supranational establishment that currently represents the world's largest and most prosperous political union. Yet, in no way it overshadows the fact that the Member States are extremely diverse in geo-political, social and cultural terms.

Predictably, other global regions, which also feature diverse members, are considering the EU's experiment in regionalization. The EU's united economic power propels it to the status of an 'economic giant' and 'financial powerhouse' able to dictate rules of the game around the world. Paradoxically, even a series of the latest Euro debt crises highlighted the EU's international reputation as a reliable economic partner - when one member stumbles, the others are helping. The economic rationales are among the leading factors when other global regions contemplate the EU's regionalization story as a lesson, a reference, a model or an example (either from positive and/or negative perspective). As such, the EU is sometimes conceptualized as a "laboratory" in regards of "external diffusion of ideas via socialization and persuasion" (Börzel and Risse 2009:8), as well as via mimicry and modeling (Börzel and Risse). While in the case of persuasion and socialization, the EU is an active agent in the diffusion of its ideas, in the latter case the EU is assessed and followed by external counterparts without the EU's active involvement. With or without the EU's involvement, there is a scholarly vision that its programmes and policies could provide a "useful and adaptable model" for other regions in the world in many political and socio-economic areas including "education, science, transport and energy networks, [and] cross-border cooperation" (Jora 2007:77).

One of such regions is Asia - a dynamic economic 'hub' with growing global ambitions. Despite (or maybe because) of Asia's increasing self-assertiveness and diversifying geo-political orientations, the EU's experiences and practices are getting "used as references in almost all meetings [in Asia] discussing regional economic cooperation" (Zhu 2007:79). This is due to the fact that the process of European integration is credited in Asia for bringing about a "stable European society and an ideal regional order" (Wang 2007:93). Does this recognition herald the onset of the process when Asia seriously considers Europe's experiences in regional community building? If yes, what Asia?

Indeed, 'Asia' is not a 'natural' region. It is a synthetic geo-political concept comprising of a variety of political regimes, religions, languages, ethnicities, traditions and histories. One way to conceptualize the world's largest continent is to assign existing Asian states into a number of geo-political groupings: Northeast, Southeast, East, South, Central, and Western Asia (Middle East in other 
categorizations). Depending on where the boundaries of Asia are drawn, even the countries of the Caucasus (Armenia, Azerbaijan and Georgia) could also be regarded as Asian.

This paper is a modest attempt to contribute to the debate on the multidimensional phenomenon of Asian regional integration, using relevant achievements on the European continent as a point of reference. Our main research question asks: "Provided that the Asian nations recognize the benefits of regional integration as exemplified by the EU, can and should Asia integrate regionally?" Modern Asia features a high number of regional organizations. This analysis considers one case-study - a regional grouping known as 'ASEAN+3' (the Association of the Southeast Asian Nations Plus Three). The participants of this group are the ten full members of the ASEAN (Brunei Darussalam, Cambodia, Indonesia, Lao PDR, Malaysia, Myanmar, the Philippines, Singapore, Thailand and Viet Nam) as well as three East Asian states of China, Japan and South Korea.

\section{ASEAN+3 and its place in the debate on Asian regionalism}

Attention to the ASEAN component in the 'ASEAN+3' formula is predictable - it is Asia's oldest regional integrative phenomenon with an established institution, the ASEAN Secretariat. Created in 1967, the organization has facilitated "achieving peace and increased interregional trade" (Murray 2010a:316) in Southeast Asia. In 1980, the ASEAN was formally exposed to the process of European integration with the EC-ASEAN Cooperation Agreement (Börzel and Risse:13) - the grouping became the European Community's (EC) first regional cooperation partner. This exposure is argued to influence some integration developments in the region, among those the adoption of the ASEAN's 2008 Charter. This document claims to spell out the organization's "institutional framework" and "accountability" measures by setting "clear targets" for the ASEAN within the next decade (ASEAN Charter Summary). While some scholars argue that the Charter 'down-loaded' few "important parts of the EU's constitutional structure" (Börzel and Risse:13), the document itself insists on the Asian inter-relations as "pragmatic market-driven" integrative activities that usually exclude "legally binding decisions" (Jora:70). As an indicator of its activities, in the period from 1976 until 2011, the ASEAN has already managed to organise 19 Summits (ASEAN Summit).

Our wider research emphasis on the ASEAN +3 is primarily driven by this grouping's acclaimed potential to become an advanced attempt of contemporary regional integration in Asia. Since the beginning of the formal collaboration in 1997 (ASEAN Plus Three Cooperation), the group's re-appearance in 1999 was framed by the Southeast and East Asia's response to the Asian Financial Crisis (Murray 2010b:600). Since then, two factors are of critical importance to this extended grouping - first, the "increasingly integrated" (Rhee and Chai 2007:43) 
East Asian financial markets, and second, special economic and political roles of China, Japan and South Korea in Asia and in the world. Currently, the East Asian 'troika' includes Asia's first, second and fifth largest economies respectively. During their November 2011 Trilateral Summit in Bali, Chinese Premier Wen Jiabao noted that "cooperation between the three nations $[\ldots]$ contributed to the stability and development of Asia and the world" (Leaders of China, Japan, South Korea Discuss Cooperation 2011). Yet, despite the integration of the markets, the 'trio' of Asian powerhouses does not explicate any intention to formalize their political relations in a narrower 'East Asian' regional grouping: the "principle of sovereignty is central in East Asia" (Murray 2010c:18). This sentiment is true for a wider Asia - "[t]here is no commitment to supranationalism or to institutionalism" (Murray 2010c:16) among Asian countries either from the North or South East. Specifically for the latter, the ASEAN is an intergovernmental body "lacking any supranational institutions" (Börzel and Risse:13), despite a voiced desire in this sub-region to "promot[e] an Asia-Pacific wide regional architecture", mainly for the "maintenance of regional peace and stability" (Natalegawa 2011). Finally, scholars agree that a certain level of confrontation between great powers in Asia is still a reality (Wang:113).

Arguably, the inter-grouping interactions in the ASEAN +3 are moderated by a number of factors. Firstly, its largest member, China, is no longer regarded to be a 'sleeping giant' of the world. On the contrary, it is an increasingly recognized political power and a mighty 'economic engine' - a situation when all markets worldwide feel "competitive pressure" (Zhu:83) from this most populous nation. We argue that in a unique way, the ASEAN+3 could serve as a 'vehicle' for China's 'return' to Asia. Having spent the last two decades on successfully building its profile as a global power, China is set for an imaginary 'comeback' to its very own continent. The contemporary Chinese scholarship emphasizes a particular strength of "the sociality and standardization of the regional society" (Wang:97), if compared with the global level. It naturally comes together with China's acceptance of "international hierarchy" (Austermann 2011:44) and the country's vision on "the regional society [that] has [...] strong regional consciousness and regional values" (Wang:98).

Secondly, there is a growing popular sentiment that the unification of the two Koreas is a remote possibility, to the degree that in the next 10-15 years the South Korean government is reported to raise about US\$50 billion in a fund for a postunified Korea (Reunification tax 2011:8). With North Korea getting accustomed to its new leadership under Kim Jong-un, only time will tell if the two parts of the Korean peninsula come together politically. But if it ever happens, leaving all possible speculations aside and keeping official South Korea's strategic view on unification in mind, the Korean North will present a unique "business opportunity" (Bowring 2005) in a more unified sub-region. As suggested, the 2018 Pyongchang Winter Olympics that is likely to create 230000 jobs and generate about US $\$ 20$ billion in investment and consumption, could also become a remarkable catalyst for the unification of the two Koreas (Choe 2011). Moreover, if a reality, 
unification would facilitate the establishment of a "security community" (Wang:106) in the East Asia.

Thirdly, Japan's strategic role in the Asian integrative activities has been dramatically reinforced after the 2009 Hatoyama Proposal (delivered by the then Prime Minister of Japan at the 64th Session of the UN General Assembly). As Murray noted, the Proposal "developed a concept of an Asian family" (Murray 2010c:11). It highlighted "a way of thinking" that could lead towards respecting "one's own freedom and individual dignity while also respecting the freedom and individual dignity of others" (Hatoyama). The document stated that Japan's "mistaken actions in the past" prevented the country from playing a "proactive role" in the process of building an East Asian community (Hatoyama). More specifically, the Japanese Prime Minister expressed his hope for "the new Japan" to be able to "overcome $[\ldots]$ history and become a 'bridge' among the countries of Asia" (Hatoyama). Such developments would arguably further facilitate regional interactions, "leaving better foundation for mutual understanding" (Wang:113) and allowing Japan to act "as an economic stabilizer" (Ding 2007:62) in the region.

Fourthly, the ASEAN's legal identity appears to be more distinct in the wake of the ASEAN Vision 2020 (adopted back in 1997). The document's clear emphasis on economic targets (the full implementation of the ASEAN Free Trade Area, liberalization of trade and services, the ASEAN Investment Area by 2010 and the investments free flow by 2020) was associated with a nouvelle (for the region) intention "to develop and strengthen ASEAN's institutions and mechanisms" (ASEAN Vision 2020). The organization's subsequent decisions to establish the ASEAN Community (Declaration on ASEAN Concord II 2003) and then adopt the ASEAN Charter (signed on 20 November 2007, in force from 15 December 2008) have significantly added to the development of the ASEAN's legal personality. Additionally, the organisation considers itself as a driving force behind the ASEAN+3 format as well - the latter group's 13th Summit, held in Hanoi in October 2010, as stated, was a reaffirmation of the participants' "strong support for ASEAN's central role in the existing regional mechanisms and in the evolving regional architecture" (ASEAN Plus Three). The following 12th ASEAN+3 Foreign Ministers' Meeting that took place in July 2011 (Bali, Indonesia) endorsed the Hanoi Summit's decision to establish the East Asia Vision Group, with six of the ASEAN+3 members immediately appointing their representatives and experts to it (ASEAN Plus Three). This consultative body had its first gathering in Seoul on 20-22 October 2011 (ASEAN Plus Three).

In summary, the four developments seem to further regional integration which is already contemplated and tried on from within the ASEAN+3 region. It is in this context that the EU's lessons and experiences are suggested to be of use to the region. This study is clear that an attempt to directly apply the EU's model to foster the process of integration within the ASEAN+3 framework is counterproductive, primarily due to historical differences between the two regional groupings (Murray 2010a:309), as well as different interpretations of the concept of liberal democracy. Thus, this analysis uses a different approach, treating the 
EU's legal composition as a leading tool to assess if the European 'know how' in regional integration could be applied to facilitate the inter-relations within the ASEAN +3 . As such, this study broadens Murray's idea that "building a region is more important than building an architecture" (Murray 2010c:6). At the same time, Moravcsik's integration 'formula' that lists "economic interest, relative power [and] credible commitments" (Moravcsik 2008:4) is effective only in the environment where legally-bound relations are counterbalancing the state of operational chaos (Vernygora and Chaban 2008a:153). This analysis explores what challenges to this reference (i.e. the corresponding legal framework is in place and constantly reinforced) exist in the ASEAN+3 grouping. The three barriers explored in this analysis are: differing democratic practices, dominating intergovernmental interactions, and the globally- (vs. regionally) orientated China. The study argues that the three challenges have a potential not only to subvert, but, paradoxically, reinforce the Asian integration process, particularly within the ASEAN +3 grouping.

\subsection{The ASEAN+3 and democracy challenge}

The ASEAN +3 unite an array of political regimes: whilst "democracy is evident in some parts of the region, it exists in conjunction with authoritarianism and communism" (Murray 2010c:18). Some of the world's leading democratic entities (Japan and South Korea) and the least corrupt countries (Singapore) are lumped into the regional group together with some of the most undemocratic regimes (Myanmar/Burma). Arguably, democratic deficits may become the key obstacle for the 'bottom-up' regional integrative initiatives. These initiatives, alongside the market-led ones, are suggested by Sally to be more instrumental for regional integration in Asia, "[r]ather than pushing top-down, government-togovernment [...] methods" (Sally 2009). In the context of this analysis, such an argument could almost lead to a suggestion that the success of the European integration was also a function of a 'bottom-up' process. In reality, it was definitely not the case. The process of European integration is typically described as an elite-driven project from its inception, a symbol and a result of a 'top-down' approach. The same applies to all of the EU's formations, starting from the European Coal and Steel Community (ECSC). Backed by a group of elite thinkers and visionaries, a French public office-holder offered a rapprochement to his county's former nemesis when Europe was still in ruins. More significantly, as a "reminiscent of the lack of national consensus during the Weimar years" (Orlow 1995:269), the idea of the ECSC came under fierce criticism even from the German opposition at the time. Not everybody in the devastated post-World War II Europe regarded the Schuman Declaration (1950) as something that would bring a prospect of "a de facto solidarity" between the European nations. In the history of Europe, there have been only few examples of such a symbolic magnitude.

Nevertheless, the EU membership (the highest form of integrative linkages in Europe) is not granted on idealistic or popular sentiments; instead, it is formal and conditional, and bears a high degree of pragmatism. What is even more 
intriguing in the debate on European integration is that the Franco-German rapprochement (the essence of the initial push towards enhancing inter-relations in the European West) is no longer the core element that holds the contemporary EU together. The success of the EU is no longer associated with "the historic Anglo-French entete" (Bull 1991:xii) either. The European integration gained a high level of comprehensiveness particularly due to its legal composition coexisting with security mechanisms; both of these factors appeared as strong community-building elements. The 1992 Maastricht Treaty on European Union made a specific statement on the following traditional legal concerns for Europe: justice, freedom and security.

Echoing the European arrangements, the ASEAN Charter emphasized the group's commitments to "enhance regional resilience by promoting greater political, security, economic and socio-cultural cooperation" (Article 1). A contemplated direct consequence of the Charter's gradual implementation, is a set of "geopolitical considerations, supranational entrepreneurship, and technocratic or ideological motives" (Nugent 1999:23), aiming at further institutionalization of integration. The Charter's rhetoric on "adherence to the rule of law, principles of democracy and constitutional government" (Article 2-h, Principle) resembles the common principles of liberal democratic societies and may seem more like a set of goals for some of the ASEAN members. But the document's provisions on the Committee of Permanent Representatives to ASEAN (Article 12), an ASEAN human rights body (Article 14), and especially the ASEAN Sectoral Ministerial Bodies (Article 10) have already triggered the mechanisms, which may lead the organization to become a more closely integrated group.

Another immensely important element of the Charter was its provision of legal continuity for the pre-Charter's "treaties, conventions, agreements, concords, declarations, [and] protocols" (Article 52, par. 2). Compared to the historical evolution of the EU's legal personality, almost every subsequent treaty on European integration could be regarded as a logical continuation of a previous one. For example, in order to prepare the supranational entity for an enlargement, the 2001 Treaty of Nice intended to "complete the process" that was initiated by the 1997 Treaty of Amsterdam (Vernygora and Chaban 2008a:157).

The legal framework of the European integration allowed the large part of the continent to gradually test the mechanisms of enhanced cooperation, moving from the ECSC to the 1957 Treaty of Rome (the document established the European Economic Community), then to the West European Union, and only then to the EU with its Maastricht Treaty. Importantly, the EU's Treaty of Lisbon - entered into force on 1 December 2009 - amended the Treaty of Rome and the Maastricht Treaty in order to optimize working methods of the entity (The Treaty of Lisbon Summary). In Asia, the ASEAN found its way to move forward via the $2007 \mathrm{Cebu}$ Declaration that announced the grouping's intention to establish an ASEAN Community by 2015 . Characteristically, the proposed Community - bearing a striking similarity to the historical development of the EU - was framed to have three pillars, namely Security, Economic and Socio-Cultural Communities (Cebu 
Declaration). Such moves seem to support the argument that the ASEAN members "have modeled parts of their institutions on the EU" (Börzel and Risse:8).

This analysis is realistic that a full replica of the European regionalization experiences in Asia is impossible, and is not necessary. While European integrative paradigms could and should be investigated by the Asian nations from a purely educational point of view, the feasibility of political and economic integration $a$-la Europe has to be questioned. Nevertheless, the ASEAN's steps in building its legal regional identity are unmistakably pointing to a number of similarities between the legal grounds for inter-relational framework in Europe and their equivalents in Asia. The future studies will have to answer the question if the ASEAN Charter was of the same importance for Asia as the Treaty of Rome was and is for Europe.

\subsection{Asia the 'intergovernmental' \& 'regional' vs. Europe the 'supranational'?}

The Asian attitudes towards supranational institutions are intermittent. For example, the ASEAN nations have been typically recognized for the utter respect of their sovereign status (Murray 2010b:599). Contrary to the process of European integration, the Southeast Asia does not show any signs to "constrain national sovereignty" (Börzel and Risse:13) in order to enhance the region-building process. Additionally, China, Japan and South Korea represent "little organizational coherence as a grouping" (Murray 2010b:600). Both domestic concerns and traditional views tainted by history are suggested to be the two main distractions for those ASEAN +3 countries to "wholeheartedly" focus on regional cooperation (Zhu:82). But does it necessarily mean that in order to foster regional integration, the ASEAN+3 nations need to concentrate on developing and adopting the supranational structures? Is there any evidence that the EU, a prominent supranational establishment, has already got rid of intergovernmental elements in its governance?

For an outsider, the EU may look like one massive monolith ruled by powerful supranational institutions, such as the European Commission, European Parliament, European Court of Justice and European Central Bank. In reality, the historical build-up of the European community and the EU's contemporary legal format allow supranational bounding mechanisms co-exist with various forms of intergovermentalism. Indeed, it is hard to imagine the UK, Germany, France or even smaller nations like Lithuania or Slovenia becoming entirely dissolved as political entities within the EU, even though "[b]orders count for very little" (The Treaty of Lisbon Summary).

While a number of federalist vectors exist in the present-day EU, it is the very innovative nature of the Union's political order and its legal composition that secures the Member States' right to act on the intergovernmental arena. Controversial and unconventional Open Method of Coordination is one of the best examples of intergovermentalism being very much 'alive' in the EU. Another example would be the newest version of the Common Foreign and Security Policy (CFSP) that, according to the Lisbon Treaty, was broadened in scope losing its 
'pillar' status whilst retaining its distinct intergovernmental elements. It could be argued that the EU's common approach in foreign policy was actually strengthened with the appointment of Baroness Catherine Ashton as the Union's High Representative for Foreign Affairs and Security Policy. Indeed, the Lisbon Treaty brought this position to the level of the European Commission's VicePresident. However, Smith (2004:262) ironically noted that France - the permanent member of the UN Security Council - would not "agree to be represented in global affairs over a five-year term by someone from Greece or Estonia". The European Stability Mechanism (Parliament Approves Treaty Change), a legal framework to safeguard the stability of the Euro-zone, was the latest addition to the intergovernmental palette of the EU. All these facts prove that intergovernmental tendencies and mechanisms remain contemporary and relevant for the current EU. Moreover, on the other side of the analytical spectrum, there is a radical view that the European continent "suffers from overpopulation of nations, not people" thus it permanently represents the "divided states of Europe" (Papic 2011).

In its diversity Europe parallels Asia, a manifold and divided continent not only on the level of states but on the level of regions. Asia's many distinct internal regions may seem to be another serious obstacle for larger-scale regional integration. Yet, given the example of the EU, it could be argued that the existence of sub-regions should not be treated as a barrier in the process of enhancing interconnections within the larger regional organization. Remarkably, the EU has legitimized the distinct "regional layer in the [...] complicated arrangement of [its] governance" (Vernygora and Chaban 2008b:128) and established a number of generously supported regional programmes; for example, Northern Dimension Program that "is focusing attention upon the uniqueness of Europe's north-eastern region as a whole" (Paet 2006). In the context of promoting and even celebrating its internal regionalism, the EU has gone even further, recognizing the phenomenon of regionalization within its Member States (Vernygora and Chaban 2008b:128). Some of the "more articulated regions - Länder in Germany or Catalunya/Cataluña in Spain - enjoy the same level of recognition as the less politically pronounced areas - West Sweden, East Finland or West Zealand" (Vernygora and Chaban 2008b:128).

Intriguingly, Asian scholars have also suggested that an accent on the regional level with the ASEAN+3 framework may counterbalance "the lack of an institutional framework for regional integration" (Zhu:82). Indeed, the contemporary Asian politico-philosophical vision stresses that "the regional society has the strong region consciousness and regional values" (Wang:98). The Asian scholarship also noted that European experience revealed that identical ideas and consensus did not complete the set of preconditions of "regional formal integration's taking-off [...]" (Wang:110-111). This argument echoes the postulates of modern functional theory, which argue that the establishment of initial cooperational linkages could be made without having "institutional structures, or even in the absence of deliberate efforts to coordinate policy" (Smith:18). 
In summary, Europe's on-going regionalization, complemented by the intergovernmental composition of the EU's high-profile advising and decision-making executive bodies (for example, the European Council) on intergovernmental level, a level of powerful self-reliant regions and non-homogeneous single market, makes the European continent comparable to Asia where the transfer of functions from the local level to the international field of interactions is happening faster than the "corresponding change of legal doctrine" (Mitrany 1975:96). Therefore, "the desire for an increasingly formalized decision-making milieu within ASEAN" (Murray 2010a:311), should not be left unnoticed. The modern format of the ASEAN arguably features the "noninterference in other member states and a rejection of supranational institutions" (Murray 2010b:599), but it is increasingly getting associated with a sense of regional community where "each state can play a different role, and have different functions" (Wang:98).

\subsection{The 'global' China and the ASEAN+3: who joins what?}

A 'rising power' of China is heralded by some observers to lead the world in terms of GDP in the coming decade (Bush 2011:13). An emerging global economic leader, China is aware that its political and economic choices will have "profound consequences for East Asia and the world" (Bush), as well as for the Asian region. Predictably, any serious region-building development in the Eastern and Southeastern Asia will have to account for China's positions and moves. But is the world's most populous nation a bit too 'global' for a regional grouping of the ASEAN+3? Is there a possibility that China may try to dominate the region to the extent that the other members of the grouping will feel being on an unequal footing if compared with this gigantic neighbour? And, in a hypothetical scenario, could the ASEAN +3 become an Asian version of the Eurasian's Commonwealth of Independent States, an international organisation of one and only dominant actor?

On this note, the EU has provided plenty of examples of equality in integrating a high number of countries with very different geo-political weights. Germany's "cooperative hegemony" (Pedersen 1998:7) is not seen as a stumbling block for maintaining the EU's day-to-day activities. Moreover, as noted by Charlie McCreedy (2009), the EU Commissioner for Internal Market and Services, the EU allowed many smaller countries "not to be dependent on big neighbours". The EU is arguably one of those modern entities where the "diversity of nationallyembedded knowledge systems" (Transformation and Sustainability of European Political Order) adds a lot of substance to the argument that the globalised economy and its further successful development very much depend on "specific territorial characteristics" (Keating 1998:16).

When it comes specifically to China, it could be characterized by its own commitment to "protect and preserve the established social and political order" (Michalski and Cheyne 2007:5) both domestically and internationally. In this light, China may be reluctant to lead and dominate a diverse and multileveled grouping and thus change the status quo. Secondly, the modern political discourse in China 
started pointing out that qualities of a deeper regionalism are essential, arguing that the "integration through globalization is not sufficient" (Rhee and Chai:43). This may mark a growing readiness of China to participate in the grouping on par with other regional players. Moreover, it was underscored by the Chinese leadership, the world's most populous nation, while getting adapted to its role as the 2012 coordinator of China-Japan-South Korea cooperation, "would like to further enhance high-level exchanges [...] and strategic trust between the three countries" (Leaders of China, Japan, south Korea Discuss Cooperation). Finally, there are audible internal calls in China to carry out "its promise of non-hegemony and prove that it is the constructive [...] but not destructive power for East Asia stability and order" (Wang:114). In this context, China's relations with Japan are seen as "especially important", and the other regional powers are encouraged "to prepare conditions to promote their positive interactions" (Wang:113).

In this light, it is Japan which is also worth looking at as a strong candidate for the informal integration leader in the grouping. As a direct consequence of the Hatoyama Proposal, Japan's engagement in the ASEAN+3 frameworks is becoming more pronounced and focused. In July 2011, during the 12th ASEAN+3 Foreign Ministers meeting, Japan "emphasized the importance of ASEANcentered regional cooperation" (12th ASEAN+3 Foreign Ministers Meeting 2011). While praising the other 12 members of the grouping for the help offered to his country after the devastating tsunami, the Japanese Foreign Minister expressed his country's readiness to join the ASEAN +3 Macroeconomic Research Office (AMRO) and take part in the process of establishing the group's Emergency Rise Reserve (12th ASEAN+3 Foreign Ministers Meeting). As a matter of fact, back in 2009, Japan together with China and South Korea were the biggest donors to the USD 120 billion multilateral currency swap mechanism (the China-initiated Chiang Mai Initiative Multilaterisation or CMIM), contributing correspondingly USD 38.4 billion, USD 38.4 billion and USD 19.2 billion (ASEAN+3 countries Deepen Financial Cooperation 2011). Arguably, such a regional effort resembles the Germany-France interactions during the Greek financial collapse in 2011.

As for the AMRO that aims to establish an independent macroeconomic surveillance and financial crisis relief mechanism, its first Director Wei Benhua refused to call the establishment 'the Asian version of the IMF' (ASEAN+3 countries Deepen Financial Cooperation). At the same time, once promoted from self-management to a more centralized administration, it could certainly become one. Is the 'Asian Euro' going to be the next step?

These processes suggest that the EU mechanisms standing behind regional integration are worthy if not the ASEAN+3's attention, then at least its curiosity. As if to prove this point, the Asian grouping is specifically interested in the EU operational capacity to pool resources in common projects and its commitment to domestic reforms, trade liberalization and political support of regional integration (Zhu:86-87). With non-hegemonic China's 'imaginary return' to Asia, the idea of the enhanced Asian integration could become a much easier task. 


\section{Conclusion}

While trying to contribute to the international scholarly debate on Asian regional integration, this paper argued that the EU's legal portrait could well be used by Asian nations as a tool in the process of assessing the EU's achievements in building inter-relations on the European continent. Our work considered one particular group of Asian countries - the ASEAN+3 - that currently represents an advanced example of the region-building in Asia. Should the grouping keep recognizing the beneficial elements of the European integration as exemplified by the framework of the EU's legal personality, it could with necessity lead the ASEAN+3 towards becoming a stronger regional organization with a distinct institutional facet. Moreover, a set of perceived barriers that are supposedly pushing the ASEAN+3 nations off the road of seamless integration - the lack of 'bottom-up' integrative approach, the predomination of intergovernmental practices and the global profile of China - could paradoxically but arguably be treated as factors reinforcing the integration within the ASEAN +3 .

In the contexts of this research, it is worthwhile mentioning that the EU's international stance is still not getting a comprehensive representation in Asia. Interestingly enough, as highlighted by a study on the EU perception in Asia (across twelve locations), the European supranational entity's self-visions as an international leader in "the fields of social affairs and human rights, environmental protection and global development [...] were among the least visible features" in Asian media, public and elite discourses (Chaban 2011:5 and 19). Moreover, as argued by some experts, the on-going euro debt crisis has presented a new image of the EU to the world - as an entity where countries are "clawing back the sovereignty they once willingly sacrificed in pursuit of a collective ideal" (Kupchan 2010).

Also, further studies on the subject could enlighten the readership to a special role of Indonesia in the Southeast Asia. An inclination of the Obama administration towards 'reloading' of the American bilateral policies in different regions could certainly make some Asian nations look at regional integration from a different perspective, too. In addition, Russia's most recent activity in re-framing the post-Soviet territory under the umbrella of the Euro-Asian Economic Community could significantly readjust the region-building status quo on the Asian continent.

Whatever form it adopts, Asian integration is and will be a unique phenomenon, based on locally-crafted original mechanisms. However, this analysis argues that if and when Asian decision-makers and academia consider the European integrative initiatives (especially, when it comes to the combination of supranational and intergovernmental arrangements), they might benefit from the insights into the EU's legal composition as a key factor in the process of integration. 
Address:

Vlad Vernygora

Tallinn University of Technology

Akadeemia tee 3

12618, Tallinn, Estonia

Phone: +3726204124

E-mail: vav13@uclive.ac.nz

\section{References}

“ASEAN+3 countries deepen financial cooperation" (2011). People's Daily Online. 6 May. Available from <http://english.peopledaily.com.cn/90001/90777/90851/7372418.html> [accessed October 2011].

"ASEAN Plus Three cooperation". Official Web-portal of the ASEAN. Available from $<\mathrm{http}: / /$ www.asean.org/16580.htm> [accessed October 2011].

"ASEAN Summit". Official Web-portal of the ASEAN. Available from <http://www.asean. org/20100.htm $>$ [accessed October 2011].

Austermann, Frauke (2011) "Bridging the sovereignty-gap of EU-China relations". In EU External Affairs Review 37-59. July.

Börzel, Tanja A. and Thomas Risse (2009) "Diffusing (Inter-) regionalism: the EU as a model of regional integration". In KFG Working Paper 7. Berlin: Freie Universitat Berlin.

Bowring, Philip (2005) "Modeling Korean unification". The New York Times, 27 September. Available from <http://www.nytimes.com/2005/09/26/opinion/26iht-edbowring.html> [accessed October 2011].

Bull, George W (1991) "Introduction". In Jean Monnet: the path to European Unity, xii-xxii, D. Brinkley and C. Hackett, eds. St. Martin's Press.

Bush, Richard (2011) "As number one, China to face hour of choice". The Korea Times. 11 August (as quoted from YaleGlobal).

Chaban, Natalia (2011) “The EU's imagery as a social, developmental and environmental actor in Asia". In EU External Affairs Review, 5-23, July.

Ding, Yibing (2007) "Symmetry of economic shocks and regional economic cooperation: a comparative empirical analysis between East Asia and the Euro area". In The EU's experience in integration: a model for ASEAN+3?, 49-62, L. Dong and G. Heiduk, eds. Bern, Berlin: Peter Lang.

Hatoyama, Yukio (2009) "Address at the 64th Session of the General Assembly of the United Nations". 24 September. New York. Available from <http://www.kantei.go.jp/foreign/ hatoyama/statement/200909/ehat 0924c e.html > [accessed October 2011].

Jora, Silviu (2007) "Patterns of development through 'Europeanization' - towards a universal modus operandi?". In The EU's experience in integration: a model for ASEAN+3?, 63-78, L. Dong and G. Heiduk, eds. Bern, Berlin: Peter Lang.

Keating, Michael (1998) "Is there a regional level of government in Europe". In Regions in Europe, 11-29. P. Le Galès and C. Lequesne, eds. London; New York: Routledge.

Kupchan, Charles (2010) “As nationalism rises, will the European Union fall?". The Washington Post. 29 August. Available from http://www.washingtonpost.com/wp-dyn/content/article/ 2010/08/27/AR2010082702138.html> [accessed November 2011].

"Leaders of China, Japan, South Korea discuss cooperation" (2011). Xinhua. 19 November. Available from <http://news.xinhuanet.com/english2010/china/2011-11/19/c_131257575. htm $>$ [accessed November 2011].

Michalski, Anna and Christine Cheyne (2007) "New Zealand and the EU: approaches to socioeconomic change in a globalising world". In Europe-New Zealand research series paper. Vol. 1, No. 1, June. Auckland: Europe Institute, the University of Auckland.

McCreedy, Charlie (2009) Remarks. 30 October. Auckland Chamber of Commerce, New Zealand. 
Mitrany, David (1975) “The process of international government (1932)”. In The Functional Theory of Politics, 85-104. London: London School of Economics and Political Science.

Moravcsik, Andrew (2008) The choice for Europe: social purpose and state power from Messina to Maastricht. Ithaca, New York: Cornell University Press. .

Murray, Philomena (2010a) "Comparative regional integration in the EU and East Asia: moving beyond integration snobbery". International Politics 47, 3-4, 308-323.

Murray, Philomena (2010b) "East Asian regionalism and EU studies". European Integration 32, 6, 597-616.

Murray, Philomena (2010c) Regionalism and community: Australia's options in the Asia-Pacific. Barton, ACT: Australian Strategic Policy Institute.

Natalegawa, Marty M. (2011) "Statement at the General Debate of the 66th Session of the UN General Assembly". 26 September 2011. New York.

Nugent, Neill (1999) The government and politics of the European Union. 4th ed. Durham, North Carolina: Duke University Press.

"Open Method of Coordination". Official Web-portal of the European Union. Available from http://europa.eu/scadplus/glossary/open_method_coordination_en.htm [accessed October 2011].

Orlow, Dietrich (1995) A history of modern Germany: 1871 to present. 3rd ed. New Jersey: PrenticeHall, Inc.

Paet, Urmas (2006) "Main guidelines of Estonia's foreign policy”. Address to Riigikogu, 6 June. Available from $<\mathrm{http}: / / \mathrm{www} . v m . e e / ? \mathrm{q}=\mathrm{en} /$ node/3659 $>$ [accessed October 2011].

Papic, Marko (2011) "The divided states of Europe". Stratfor, 28 June. Available from $<$ http://www.stratfor.com/19889> [accessed December 2011].

"Parliament approves Treaty change to allow stability mechanism" (2011). Official Web-portal of the European Union. Available from <http:/www.europarl.europa.eu/en/headlines/content/ 20110322FCS16061/003/html/Parliament-approves-Treaty-change-to-allow-stabilitymechanism $>$ [accessed October 2011].

Pedersen, Thomas (1998) Germany, France, and the integration of Europe: a realist interpretation. London and New York: Pinter Publishers.

"Reunification tax" (2011). The Korea Times. 19 July.

Rhee, Yeongseap and Hee-Yul Chai (2007) "Comparison financial integration process between East Asia and Europe". In The EU's experience in integration: a model for ASEAN+3?, 25-47, L. Dong and G. Heiduk, eds. Bern, Berlin: Peter Lang.

Sally, Razeen (2009) "The truth about Asian integration". The Wall Street Journal, 28 October.

Sang-hun, Choe (2011) “Twice-rejected S. Korean town lands 2018 Winter Games". The New York Times, 7 July. Available from <http://www.nytimes.com/2011/07/08/sports/olympics/08ihtoly08.html $>$ [accessed October 2011].

Smith, Michael (2004) Europe's Foreign and Security Policy. The institutionalization of cooperation. Cambridge: Cambridge University Press.

"The transformation and sustainability of European political order". ARENA Official Web-portal.

Available from <http://www.sv.uio.no/arena/forskning/prosjekter/eurotrans/index.html> [accessed October 2011].

Vernygora, Vlad and Natalia Chaban (2008a) "An invisible giant: a 'snapshot' of the EU as a subject of juridical interactions". In Socio-economic environment: harmonisation in the EU Ccountries of Baltic Sea Rim, 153-166. A. Kirch and T. Kerikmae, eds. Tallinn: Institute for European Studies, International University Audentes Collection.

Vernygora, Vlad and Natalia Chaban (2008b) "New Europe and its neo-regionalism: the working case of the Community of Democratic Choice". Trames 12, 2, 127-150.

Wang, Xueyu (2007) "Integration and the peaceful change of regional order: European experience and East Asian strategic choice". In The EU's experience in integration: a model for $A S E A N+3$ ?, 93-115, L. Dong and G. Heiduk, eds. Bern, Berlin: Peter Lang.

Zhu, Jiancheng (2007) "Enlightenment of European integration to ASEAN+3". In The EU'S experience in integration: a model for ASEAN+3?, 79-90, L. Dong and G. Heiduk, eds. Bern, Berlin: Peter Lang. 
"12th ASEAN+3 Foreign Ministers meeting" (2011). The Official Web-portal of the Ministry of Foreign Affairs of Japan. 26 July. Available from <http://www.mofa.go.jp/announce/jfpu/ 2011/7/0726_01.html> [accessed October 2011].

\section{Legal documents}

ASEAN Charter (2007) Available from <http://www.aseansec.org/publications/ASEANCharter.pdf $>$ [accessed October 2011].

ASEAN Charter Summary. Available from <http://www.asean.org/21861.htm $>$ [accessed October 2011].

ASEAN Vision (2020) Available from $<$ http://www.asean.org/1814.htm $>$ [accessed October 2011].

The Cebu Declaration (2007) Available from $<\mathrm{http}: / /$ www.asean.org/19260.htm $>$ [accessed October 2011].

Declaration on ASEAN Concord II (Bali Concord II). Available from <http://www.asean.org/ 15159.htm $>$ [accessed October 2011].

The Maastricht Treaty (1992) Available from <http://www.eurotreaties.com/maastrichtec.pdf $>$ [accessed October 2011].

The Treaty of Lisbon Summary. Available from <http://europa.eu/lisbon_treaty/index_en.htm> [accessed October 2011].

Schuman Declaration (1950) Available from <http://www.eppgroup.eu/Activities/docs/divers/ schuman-en.pdf $>$ [accessed October 2011]. 